\title{
Aikuiskasvatustieteen opiskelemisesta Helsingissä
} Pääaineesta sulautettuihin sisältöihin

Tutkinnonuudistuksen aattona Helsingin yliopiston kasvatustieteen laitoksella keskusteltiin vilkkaasti. Aikuiskasvatustieteen yhdistyessä yleiseen kasvatustieteeseen niin henkilökunta kuin opiskelijatkin enteilivät aikuiskasvatustieteen roolin muuttuvan perustavanlaatuisella tavalla. Siinä missä osa opiskelijoista oli huolissaan mahdollisuuksista opiskella aikuiskasvatustiedettä tulevaisuudessa, osa oli luottavaisin mielin yhteisen pääaineen tarjoamia mahdollisuuksia silmällä pitäen.

Kehittävän työntutkimuksen lisäksi selkeästi aikuiskasvatustieteeseen kytkeytyvät kurssit näyttävät ensi silmäyksellä olevan tätä nykyään harvassa. Kasvatustieteen dosentti ja aikuiskasvatustieteen yliopistonlehtori Merja Ikonen-Varila kuitenkin muistuttaa, että yksittäisien kurssien ohella entisen pääaineen tarjonta on sulautettu tutkintorakenteeseen läpäisevänä osana.

”Sen tulisi näkyä opiskelijoille siten, että kaikille yhteisen materiaalin ohella kirjallisuus jakautuisi kasvatus- ja aikuiskasvatustieteeseen. Opettajan näkökulmasta aikuiskasvatustieteen asema onkin periaatteessa vahvistunut opetussuunnitelmassa”, Ikonen-Varila totesi. Kun kurssitarjontaa silmäilee lähemmin, huomaa useimpien opintojaksojen tarjoavan mahdollisuuden perehtyä aikuisen ja organisaatioiden oppimiseen, asiantuntijuuteen sekä työn ja toiminnan muutosprosesseihin, jotka lukeutuivat aiemmin eritoten aikuiskasvatustieteen opintoihin. Kaikille pääaineopiskelijoille avoimien opintojen ohella aikuiskasvatustiedettä hallitsevaa kehittävää työntutkimusta on nykyisin mahdollista opiskella kahden vuoden välein käynnistyvässä Aikuiskasvatustieteen ja työn kehittämisen maisteriohjelmassa. Maisteriohjelmassa kuitenkin opiskelee kerrallaan vain kymmenkunta opiskelijaa, joiden joukossa ei ole toistaiseksi nähty kasvatustieteen pääaineopiskelijoita.

”Toinen kysymys onkin, miten opetussuunnitelmassa näkyvä jako välittyy opiskelijoille, koska suuri osa aikuiskasvatustieteen henkilökunnasta on kehittävän työntutkimuksen puolella, ja heidät on sijoitettu Teollisuuskadulle, kauas laitoksesta. He tekevät paljon mielenkiintoista ja monipuolista tutkimusta, jota tunnetaan valitettavan huonosti. Lehtori Leena Ahteenmäki-Pelkonen puolestaan on edustanut aikuiskasvatustieteen perinteistä näkökulmaa, mm. vapaata sivistystyötä, mutta hän on ollut paljon poissa. Näin ollen aikuiskasvatustiedettä leimaa tietty henkilöihin sidottu haavoittuvuus”, Ikonen-Varila kokosi.

Aikuiskasvatustieteen opiskelulle näyttää olevan leimallista, ettei opiskelijoiden suuntautuminen palaudu vain laitoksen tutkimuksen painopistealueisiin vaan myös sivuainevalintoihin: suosittuina sivuaineina johtaminen, työpsykologia, sosiaalipsykologia sekä sosiologia käyvät jatkuvaa vuoropuhelua pääaineopintojen kanssa. Kasvatustieteilijän toimintakentät -kurssilla opiskelijat taas ovat päässeet tutustumaan työelämässä vaikuttaviin kasvatustieteilijöihin, mm. koulutussuunnittelijoihin ja konsultteihin, joiden kokemuksissa ilmenevät työelämään kytkeytyvän aikuiskasvatustieteen ja suosittujen sivuaineiden yhteiset painotukset.

”Tässäkin suhteessa aikuiskasvatustiede näyttää olevan voimissaan. Amanuenssi Tuomo Aallon periaatteena on ollut, että kurssille otettaisiin puhumaan hiljattain valmistuneita kasvatustieteilijöitä, jotka pystyvät luontevasti kytkemään työelämän näkökulman opintojen osa-alueisiin. Ilmeisesti opiskelijat kuitenkin kritisoivat, että kurssilla oli ollut hyvin vähän puhetta järjestöistä ja vapaasta sivistystyöstä, mutta kertooko se siitä, ettei opiskelijoitamme ole suuntautunut sinne?”

Ikonen-Varilan mukaan kysymys aikuiskasvatustieteen tämänhetkisestä tilasta onkin suhteutettava siihen, mikä ylipäätään mielletään aikuiskasvatustieteeksi. Tämänhetkisen linjauksen viestimistä helpottaisikin selkeästi perinteisien suuntauksien parissa työskentelevä henkilökunta.

”Voi olla, että kirjallisuuden ja opiskelijan väliin vaadittaisiin vahva persoona, joka tutkisi ja toimisi alueella. Silloin opetussuunnitelman tasolla näkyvä aikuiskasvatustieteen painotus kenties välittyisi entistä paremmin myös opiskelijoille.”

Asko Kauppinen \& Elina Manninen 